\title{
Influence of maturity stage on fruit longevity of cherry tomatoes stored at ambient and controlled temperature
}

\author{
Influência do estádio de maturação na longevidade de frutos de \\ tomate cereja armazenados sob temperatura ambiente e controlada
}

\author{
Cristiana Maia de Oliveira ${ }^{1 *}$; Leandro Martins Ferreira ${ }^{2}$; \\ Margarida Goréte Ferreira do Carmo ${ }^{3}$; Regina Celi Cavestré Coneglian ${ }^{3}$
}

\begin{abstract}
Fruit maturity stage has direct influence on the post-harvest life and consumer quality. Therefore, the understanding of the maturation process and its quality characteristics for storage are key factors for commercialization. In face of the foregoing, this study aimed to determine shelf life and changes in physical and chemical indexes of cherry tomatoes (Perinha Água Branca (PAB) and Mascot), assessing fruit harvested at four maturity stages and stored at ambient and controlled temperatures. For this, it was used fruit at turning, pink, red and ripe maturity stages, submitted to ambient $\left(25 \pm 2{ }^{\circ} \mathrm{C}\right)$ and controlled $\left(12{ }^{\circ} \mathrm{C}\right.$ and $\left.90 \% \mathrm{RH}\right)$ temperature, and assessed over time the indexes of fresh mass loss, titratable acidity, $\mathrm{pH}$, soluble solids and ascorbic acid. The experimental design was completely randomized design in a factorial scheme of $2 \times 4 \times 7$ for ambient temperature and $2 \times 4 \times 8$ for controlled temperature. At ambient temperature, a longevity of up to 20 days was observed for PAB and Mascot fruit harvested at turning and pink maturity stages. When harvested at red and ripe stages, the longevity was of 15 days for PAB fruit and of 15 and 11 days, respectively, for Mascot fruit. At controlled temperature, PAB fruit showed longevity of 24 days when harvested at turning and pink stages and of 20 and 7 days, respectively, when harvested at red and ripe stages. A longevity of up to 27 days was observed for Mascot fruit harvested at turning stage and of 24 days for the other stages. The fruit harvested at turning and pink maturity stages, associated with storage under controlled conditions, presented higher longevity and maintenance of physical and chemical indexes of quality.
\end{abstract}

Key words: Solanum lycopersicum. Maturity stage. Post-harvest.

\section{Resumo}

O estádio de maturação do fruto influencia diretamente na sua vida pós-colheita e na escolha por parte do consumidor, por isso o entendimento do processo de maturação e de suas características de qualidade para o armazenamento são fatores fundamentais para a comercialização. Diante disso, este trabalho teve por objetivo determinar o tempo de prateleira e alterações dos índices físicos e químicos em frutos de tomate do grupo cereja (Perinha Água Branca (PAB) e Mascot), colhidos em quatro estádios de maturação e armazenados sob temperatura ambiente e controlada. Para issa, foram utilizados frutos nos estádios de maturação: de vez, rosado, vermelho e maduro, submetidos às temperaturas: ambiente $\left(25 \pm 2{ }^{\circ} \mathrm{C}\right)$ e controlada $\left(12{ }^{\circ} \mathrm{C}\right.$ e UR de $\left.90 \%\right)$ e avaliados os índices de perda de massa fresca, acidez titulável, $\mathrm{pH}$, sólidos solúveis e ácido ascórbico ao longo do tempo. O delineamento experimental foi

\footnotetext{
${ }^{1}$ Discente do Curso de Doutorado do Programa de Pós-Graduação em Fitotecnia, Universidade Federal Rural do Rio de Janeiro, UFRRJ, Seropédica, RJ, Brasil. E-mail: cristiana.maia@hotmail.com

${ }^{2}$ Discente do Curso de Doutorado do Programa de Pós-Graduação em Ciência dos Solos, UFRRJ, Seropédica, RJ, Brasil. E-mail: leandroctur@hotmail.com

${ }^{3}$ Prof ${ }^{\text {as }}$, Departamento de Fitotecnia, UFRRJ, Seropédica, RJ, Brasil. E-mail: gorete@ufrrj.br; rccconeg@ufrrj.br

* Author for correspondence
} 
inteiramente casualisado em um fatorial $2 \times 4 \times 7$ para temperatura ambiente e $2 \times 4 \times 8$ para temperatura controlada. Em temperatura ambiente, longevidade de até 20 dias foi observada para frutos de PAB e Mascot colhidos nos estádios de maturação de vez e rosado. Quando colhidos nos estádios vermelho e maduro a longevidade foi de 15 dias para os frutos de PAB, e de 15 e 11 dias, respectivamente para os frutos de Mascot. Em temperatura controlada, frutos de PAB apresentaram longevidade de 24 dias quando colhidos de vez e rosado e de 20 e 7 dias, respectivamente, quando colhidos vermelho e maduro. Longevidade de até 27 dias foi observada para Mascot em frutos colhidos no estádio de vez e de 24 dias para os demais estádios. Frutos colhidos no estádio de maturação de vez e rosado associado ao armazenamento em condições controladas apresentam maior longevidade e manutenção dos índices físicos e químicos de qualidade.

Palavras-chave: Solanum lycopersicum. Estádio de maturação. Pós-colheita.

\section{Introduction}

Tomato is a climacteric fruit and its maturation begins at the distal portion and gradually extends to the base (ALEXANDER; GRIERSON, 2002). This process entails a series of changes in fruit physical and chemical characteristics such as acidity, soluble solids, enzyme activity, appearance, texture, size and juiciness (MONTEIRO et al., 2008, OLIVEIRA et al., 2015). Perishability is directly related to respiration process continuing, even after being harvest, reducing thus shelf life and marketing (COSTA et al., 2011).

In tomatoes, post-harvest changes and fruit longevity are mainly affected by damages caused during harvest until the consumer's table. Such damages can be mechanical, physiological or pathological, causing injuries that compromise fruit quality, as well as changes in senescence process (CHITARRA; CHITARRA, 2005).

The ideal harvest time of tomato may vary according to the market segment to be served, i.e., processing or table. The latter also depends on the consumer market characteristics, such as distance from the farming area (FERREIRA et al., 2012). In general, green fruit have longer life cycle and are resistant to transport, however, lack quality if compared to those at latter stages. It is thereby recommended, for fresh consumption, harvesting fruit at physiological maturity point; since despite having worse sensory qualities, they are less perishable, withstand mechanical damage during harvest, classification, transportation and commercialization, showing, therefore, improved shelf life (BRACKMANN et al., 2007).

Several techniques may be adopted to extend post-harvest longevity as increasing air relative humidity, reducing temperature and using of modified atmosphere (LEMOS et al., 2008, MIZOBUTSI et al., 2012). Lower temperatures during storage slow down ripening and senescence, as well as minimizing color variation, weight loss, firmness loss and biochemical transformations. At higher temperatures, physical and chemical transformations are accentuated (FERREIRA et al., 2010), impairing quality level as by loss of turgescence. Refrigerated storage is one of the easiest solution to extend post-harvest lifespan; for tomatoes, temperatures from 8 to $13{ }^{\circ} \mathrm{C}$ are recommended, which vary with maturity stage (LUENGO, 2001). Regrettably, there still are no studies for the cherry tomato group, comparing fruit longevity when harvested at different maturity stages and stored under controlled temperature.

Harvesting has direct influence on shelf life and consumerchoices; thereby, understanding maturation process, and how it affects fruit characteristics and quality whilst in storage, represent key factors for commercialization (FERREIRA et al., 2010).

Considering the above, this study aimed to determine the shelf life of cherry tomatoes harvested at four maturity stages, and stored at ambient and controlled temperature. Aside from that, it was assessed changes in physical and chemical indexes, fresh mass loss, titratable acidity, $\mathrm{pH}$, soluble solids and ascorbic acid over time. 


\section{Material and Methods}

This study was carried out at the Department of Horticulture, Federal Rural University of Rio de Janeiro (UFRRJ), under an organic management. Cherry tomatoes of Perinha Água Branca (PAB) variety and Mascot hybrid were used. The seedlings were cultivated in expanded polystyrene trays with 128 cells in a greenhouse and transplanted 30 days after sowing.

For longevity assessment, fruit were harvested at four maturity stages, according to Brasil (1995): turning (between $10 \%$ and $30 \%$ of the colors yellow, red or pink), pink (from $30 \%$ to $60 \%$ of the fruit colored in red), red $(60 \%$ to $90 \%$ of the fruit is red) and ripe (more than $90 \%$ of the fruit is red). Subsequently, the fruit were transported to the Post-Harvest Laboratory of the Department of Plant Science located at the UFRRJ, being selected and standardized considering the degree of maturation and sanitized with a solution containing $100 \mathrm{mg} \mathrm{L}^{-1}$ of active chloride.

The fruit were placed in plastic boxes with eight holes in its surface to allow gas exchange and stored under two conditions: ambient temperature $(25 \pm 2$ ${ }^{\circ} \mathrm{C}$ ) and in a BOD adjusted to $12{ }^{\circ} \mathrm{C}$ and $90 \% \mathrm{RH}$. The design adopted was completely randomized in a factorial $2 \times 4 \times 7(8)$, i.e., two cultivars (PAB and Mascot), four maturity stages (turning, pink, red and ripe) and seven or eight assessment times counted from the test installation, and four replicates represented by a tray containing five fruit each. The assessments were performed at $0,3,7,11,15,20$ and 24 days for the fruit stored at ambient conditions and up to 27 days for the fruit stored in BOD.

The analysis was carried out to the maximum point of fruit durability, according to the initial degree of maturation and storage temperature. Over the storage time, it was conducted the assessments for the physical and chemical indexes of fresh mass loss, titratable acidity, $\mathrm{pH}$, soluble solids and ascorbic acid.
The mass loss was obtained using the following equation: mass loss $=($ initial mass - final mass $)$ / (initial mass) $\times 100$ and the results expressed as a percentage $(\%)$. The titratable acidity was obtained using $10 \mathrm{~g}$ of the diluted sample in $100 \mathrm{~mL}$ of distilled water under moderate agitation. This solution was titrated with $0.1 \mathrm{~N} \mathrm{NaOH}$ until the $\mathrm{pH}$ range of 8.2 to 8.4 (IAL, 2008) and the results expressed in $\mathrm{mg}$ of citric acid $100 \mathrm{~g} \mathrm{pulp}^{-1}$. The $\mathrm{pH}$ reading was carried out using $10 \mathrm{~g}$ of diluted pulp in $100 \mathrm{~mL}$ of distilled water. The soluble solids were determined by direct reading using a manual refractometer, with the results expressed in degrees Brix (IAL, 2008), and the ascorbic acid was determined according to the modified Tillmans method (BRASIL, 1986; ITAL, 1990; PEARSON, 1976), with values expressed in $\mathrm{mg}$ of ascorbic acid in $100 \mathrm{~g}$ of pulp.

The data were submitted to analysis of variance $(\mathrm{p}<0.05)$ and first and second order regression analysis for the effect of storage time and Tukey's test for comparison of cultivars and the different maturity stages tested. The software used in the statistical analysis was the SISVAR for Windows, version 4.0 (FERREIRA, 2000).

\section{Results and Discussion}

Longevity of fruit stored at ambient temperature (25 ${ }^{\circ} \mathrm{C} \pm 2{ }^{\circ} \mathrm{C}$ )

The life cycle of fruit varied according to the cultivar and harvested maturity stage. Fruit harvested at turning, pink, red and ripe stages of both cultivars presented similar behavior and tendency of fresh mass reduction over the storage period (Figure 1A and 1B). This reduction in fresh mass is due to water loss by transpiration and metabolic processes of respiration (BRACKMANN et al., 2007). Based on the maximum reference rate of 7\% for fresh mass loss in tomato (CHITARRA; CHITARRA, 2005), PAB fruit harvested turning and pink showed longevity of 20 days, while those harvested red or ripe showed longevity of 15 days. Mascot fruit harvested turning and pink presented 
longevity of 20 days, those harvested red 15 days, and those harvested ripe showed longevity of 11 days. A study at ambient temperature at $25^{\circ} \mathrm{C}$, conducted by Aguiar et al. (2012), estimated the life cycle of 10 days for Sweet Grape and Cereja Coco cherry tomatoes at maturity stage ready for sale. This result shows a similar shelf life for Mascot and those cited cultivars when harvested at ripe stage, while the cultivar PAB shows longevity higher (15 days). Furthermore, this time may be extended if the fruit are harvested at turning and pink stages.

A higher average loss of fresh mass was observed in fruit harvested turning compared to those harvested red or ripe in both cultivars. However, fruit at turning maturity stage of the cultivar Mascot showed higher average loss $(4.92 \%)$ than those of PAB (3.92\%). This result is due to the higher postharvest durability of these fruit when compared to red or ripe stages, i.e., the fruit harvested red or ripe start their senescence faster while those harvested turning or pink remain intact longer and continue to lose water until the end of the storage (Table 1). The water loss contributes to loss of weight and appearance and, therefore, to fruit quality (CASA; EVANGELISTA, 2009). Moreover, this fresh mass loss is higher in fruit stored at ambient temperature due to the increase in transpiration rates (JAVANMARDI et al., 2006).

The lowest $\mathrm{pH}$ values were recorded for $\mathrm{PAB}$ fruit harvested turning (4.59) and the highest for the PAB fruit harvested ripe (4.77). In both cultivars, the $\mathrm{pH}$ value was higher in fruit harvested at more advanced stages of maturation. Mascot fruit, regardless maturation degree, presented lower $\mathrm{pH}$ values when compared to PAB fruit (Table 1). Such $\mathrm{pH}$ values are higher than those encountered by
Guilherme et al. (2014) in cherry tomatoes, who measured values below 4.5. This increase in $\mathrm{pH}$ during the fruit storage is due to the respiratory process in the maturation that leads to the decrease of organic acids and increase of soluble solids (AGUIAR et al., 2012).

The acidity of the fruit at turning, pink and red maturity stages in the cultivar PAB and at turning and pink stages in tomato fruit of Mascot presented a downward tendency over time. Mascot fruit harvested red or ripe presented decreased acidity up to the 11th day and slight increase in the last assessment, 15 days after harvest (Figures $1 \mathrm{C}$ and 1D).

Regarding the maturation degree of fruit, higher average values of titratable acidity were observed in Mascot fruit harvested pink (0.60), red (0.65) or ripe (0.70) when compared to turning (0.53), i.e., the acidity values were higher in fruit with more advanced stages of maturation. In PAB fruit, the acidity was higher in fruit harvested turning when compared to pink fruit (Table 1). According to Bron and Jacomino (2006), the acidity during the maturation process may increase or decrease. Thus, the increase would be related to the formation of galacturonic acid from pectin degradation, while the acidity reduction is due to organic acids oxidation, which is due to the respiratory process.

The soluble solids content of the fruit of both cultivars only showed significant values $(p<0.05)$ for the fruit harvested at pink stage (Figures $1 \mathrm{E}$ and 1F). PAB fruit showed ${ }^{\circ}$ Brix ranging from 6 and 7 , with maximum value at 20 days. On the other hand, for Mascot fruit, the ${ }^{\circ}$ Brix ranged between 6 and 7.5 , with maximum value at 15 days (Figures $1 \mathrm{E}$ and $1 \mathrm{~F})$. 
Figure 1. Longevity of cherry tomato fruit at turning, pink, red and ripe maturity points of the cultivars Perinha Água Branca (PAB) and Mascot stored at ambient temperature $\left(25^{\circ} \mathrm{C} \pm 2{ }^{\circ} \mathrm{C}\right)$. A and B) Fresh mass loss; C and D) Titratable acidity; and $\mathrm{E}$ and F) Soluble solids. The treatments not presented in the figure were not significant by the F test at $5 \%$ probability level, within the respective assessed times for PAB and Mascot.

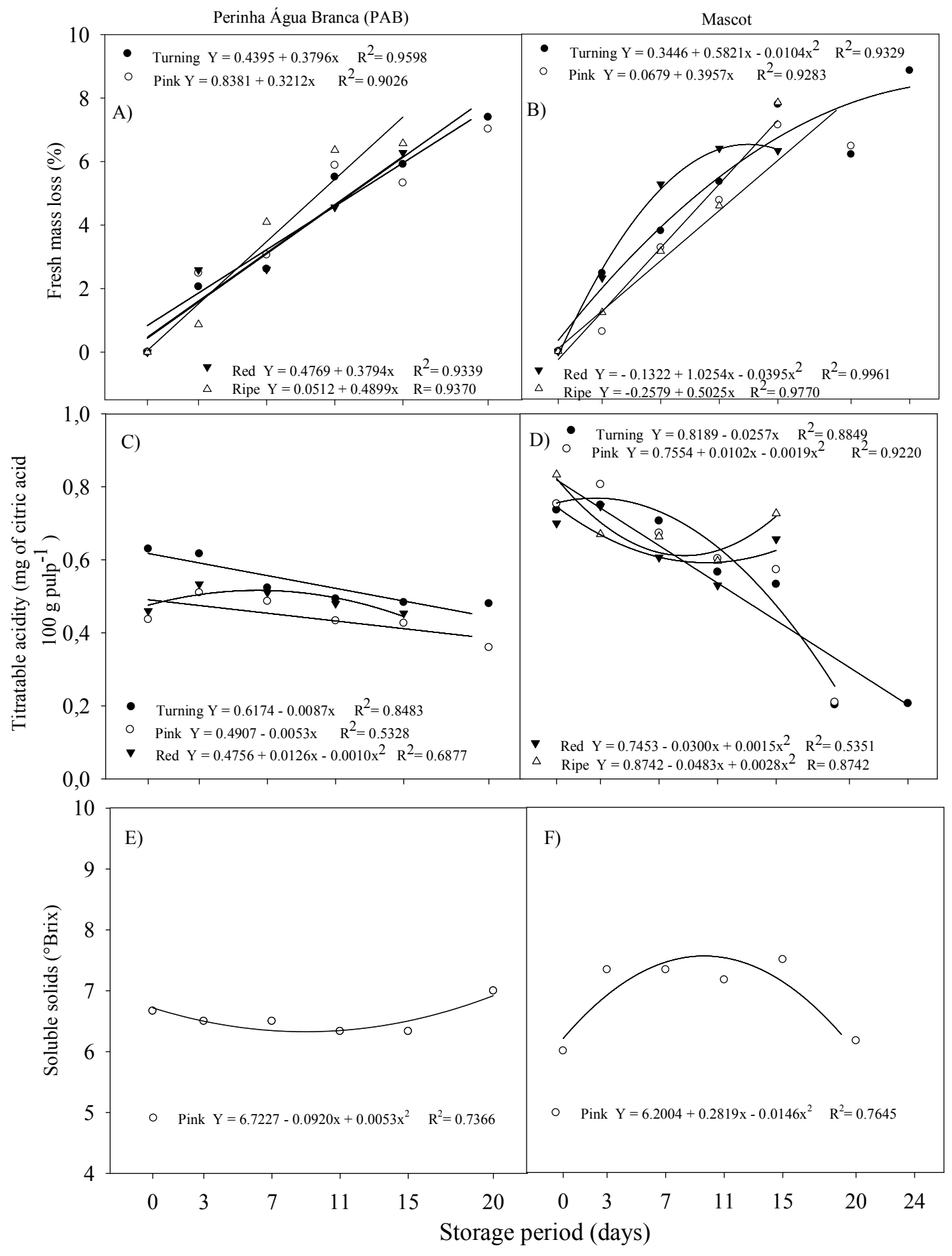


Table 1. Averages of fresh mass loss, $\mathrm{pH}$, titratable acidity, soluble solids and ascorbic acid in fruit of cherry tomato of the cultivars Perinha Água Branca (PAB) and Mascot stored at ambient temperature $\left(25^{\circ} \mathrm{C} \pm 2{ }^{\circ} \mathrm{C}\right)$.

\begin{tabular}{|c|c|c|c|c|c|c|c|c|c|c|}
\hline \multirow[b]{2}{*}{$\begin{array}{l}\text { Maturity } \\
\text { stages }\end{array}$} & \multicolumn{2}{|c|}{$\begin{array}{l}\text { Fresh mass loss } \\
\qquad(\%)\end{array}$} & \multicolumn{2}{|c|}{$\mathrm{pH}$} & \multicolumn{2}{|c|}{$\begin{array}{l}\text { Titratable acidity } \\
\text { (mg of citric acid } \\
100 \mathrm{~g} \mathrm{pulp}^{-1} \text { ) }\end{array}$} & \multicolumn{2}{|c|}{$\begin{array}{l}\text { Soluble solids } \\
\left.\text { ( }{ }^{\circ} \text { Brix }\right)\end{array}$} & \multicolumn{2}{|c|}{$\begin{array}{c}\text { Ascorbic acid } \\
\text { (mg of ascorbic acid } \\
100 \mathrm{~g} \text { of pulp }{ }^{-1} \text { ) }\end{array}$} \\
\hline & PAB & Mascot & PAB & Mascot & PAB & Mascot & PAB & Mascot & PAB & Mascot \\
\hline Turning & $3.92 \mathrm{Ba}$ & $4.92 \mathrm{Aa}$ & 4.59Ac & 4.30Bab & $0.54 \mathrm{Aa}$ & $0.53 \mathrm{Ac}$ & $6.50 \mathrm{Aa}$ & $6.62 \mathrm{Ac}$ & $33.33 \mathrm{Ac}$ & $40.47 \mathrm{Ac}$ \\
\hline Pink & 3.97Aa & 3.69Abc & $4.71 \mathrm{Ab}$ & $4.29 \mathrm{Bb}$ & $0.44 \mathrm{Bb}$ & $0.60 \mathrm{Ab}$ & $6.55 \mathrm{Ba}$ & $6.92 \mathrm{Ac}$ & $25.00 \mathrm{Bc}$ & $35.18 \mathrm{Ac}$ \\
\hline Red & $3.21 \mathrm{Bb}$ & $4.06 \mathrm{Ab}$ & $4.68 \mathrm{Ab}$ & 4.32Bab & 0.49Bab & $0.65 \mathrm{Aab}$ & $6.83 \mathrm{Ba}$ & $7.80 \mathrm{Ab}$ & 66.67Aa & $63.33 \mathrm{Ab}$ \\
\hline Ripe & $.58 \mathrm{Aab}$ & $3.36 \mathrm{Ac}$ & 4.77Aa & $4.35 \mathrm{Ba}$ & $0.47 \mathrm{Bab}$ & $0.70 \mathrm{Aa}$ & $6.83 \mathrm{Ba}$ & $8.43 \mathrm{Aa}$ & $47.78 \mathrm{Bb}$ & $86.67 \mathrm{Aa}$ \\
\hline CV (\%) & \multicolumn{2}{|c|}{17.71} & \multicolumn{2}{|c|}{1.37} & \multicolumn{2}{|c|}{14.40} & \multicolumn{2}{|c|}{5.95} & \multicolumn{2}{|c|}{27.17} \\
\hline
\end{tabular}

* Means followed by the same uppercase letters on columns and lowercase letters on rows do not differ significantly by the Tukey's test at $5 \%$ probability.

In Table 1, comparing the two cultivars, there were no differences regarding the soluble solids content of the fruit harvested turning. However, for the other maturity stages, higher averages of ${ }^{\circ}$ Brix was recorded in Mascot fruit. In PAB fruit, there were no significant differences regarding the average soluble solids content as a function of the maturity stage considering the harvest time. Mascot fruit, on the other hand, showed increases as they were harvested at more advanced stages of maturation, with an average ${ }^{\circ}$ Brix value from 6.62 in the turning fruit to 8.43 in the ripe fruit. Opara et al. (2012) also reported increases in soluble solids content in fruit of cherry tomatoes, with the evolution of maturation from green-ripe to red-intense ranging from 5.0 to $8.7^{\circ}$ Brix, respectively, corroborating the data found in this study.

The average contents of ascorbic acid of PAB fruit ranged from 25.00 to $66.67 \mathrm{mg}$ and from 35.18 to $86.67 \mathrm{mg}$ in Mascot fruit, with lower values at turning and pink stages and higher values at red and ripe stages (Table 1). The highest values observed at red and ripe stages may have occurred because these fruit were harvested at a stage of full maturation when compared to fruit that have completed their maturation process out of the parent plant (FERREIRA et al., 2010; SOUZA et al., 2011).

\section{Longevity of fruit stored at controlled temperature $\left(12{ }^{\circ} \mathrm{C}\right.$ and $\left.90 \% \mathrm{RH}\right)$}

To observe whether fruit longevity could be extended in a controlled environment and which would be an optimal harvest point for maximum longevity without significant quality loss, some fruit were submitted to $12{ }^{\circ} \mathrm{C}$ and $90 \% \mathrm{RH}$ for up to 27 days, with samplings performed over time to assess the physical and chemical quality indexes.

PAB fruit life cycle was of 24 days for those harvested at turning or pink stages, and of 7 and 20 days for those harvested at red and ripe stages, respectively. In contrast, Mascot fruit showed life cycle of 27 days when harvested turning and of 24 days when harvested at pink, red or ripe stages. Such longevity is based on fresh mass loss acceptable values stated by Chitarra and Chitarra (2005).

Fresh mass loss increased as a function of storage time, regardless cultivar or maturity point, but with less variation within each time assessed for some stages in Mascot fruit and larger variations in PAB fruit, especially in ripe stage. The highest loss $(10.45 \%)$ was recorded at 15 days of storage in PAB fruit harvested at ripe stage; for Mascot fruit at the same maturation degree, the loss was only of $3 \%$ (Figures 2A and 2B). The fresh mass loss recorded in PAB fruit are above the average cited by Chitarra and Chitarra (2005) as acceptable for tomato. For 
this reason, this cultivar should not be harvested at ripe stage and stored under controlled conditions.

Table 2 shows that the highest average of fresh mass loss in PAB fruit occurred for ripe stage and the lowest value was observed at turning stage when compared to each other. On the other hand, for Mascot fruit the average of fresh mass loss at the different maturity stages did not present statistical difference. According to Kluge et al. (1996), riper fruit offer less resistance to fresh mass loss when compared to greener fruit because they are at the end of the senescence process. When comparing the two cultivars at the different maturity stages, it was found that only the ripe stage differed significantly and that the fruit of the cultivar PAB at this stage presented higher fresh mass loss (Table 2).

The average $\mathrm{pH}$ value was higher for $\mathrm{PAB}$ fruit harvested at ripe (4.93) and red (4.85) stages, followed by fruit harvested at pink (4.84) and turning (4.57) stages. Higher $\mathrm{pH}$ values were also registered for Mascot fruit harvested ripe (4.31) when compared to fruit harvested at pink (4.22) and turning (4.17) stages (Table 2). According to Anthon et al. (2011), an increase in fruit pH occurs as they ripen, being this increment higher when the fruit reach the red-ripe stage in the plant.

In general, $\mathrm{PAB}$ fruit showed higher $\mathrm{pH}$ values and lower acidity when compared to Mascot fruit at all assessed stages. The acidity of Mascot fruit at the different maturity stages ranged from 0.67 to 0.72 $\mathrm{mg}$ of citric acid $100 \mathrm{~g}$ pulp ${ }^{-1}$ and of PAB fruit from 0.49 to $0.60 \mathrm{mg}$ of citric acid $100 \mathrm{~g} \mathrm{pulp}^{-1}$.

A decrease in the acidity was observed in PAB fruit along the maturation process with maximum and minimum values equal to 0.59 and 0.43 , respectively, in the initial and final assessment of fruit harvested at pink stage. This decrease in acidity is consistent with the reported by Xin et al. (2010), who also observed a decrease in the titratable acidity with the maturation of tomato fruit. In Mascot fruit, as observed for $\mathrm{pH}$ values, a wide variation in acidity values was observed during the storage time (Figures 2C and 2D). According to Ferreira (2010), the acidity tends to decrease with the progress of the fruit maturity stage and achieve higher values at turning stage, gradually reducing with fruit maturation. This was observed among the PAB maturity stages, in which turning fruit stood out significantly due to the higher acidity while in Mascot fruit there was no variation in the contents among the maturity stages (Table 2). A similar behavior to the Mascot hybrid was observed in fruit of long shelf-life tomato of the cultivar Cronus, in which the acidity was not affected by temperature and fruit maturity stage (BRACKMANN et al., 2007).

Soluble solids fluctuated within a fairly range for PAB harvested at turning and pink stages; nonetheless, for those harvested red and ripe, these values tended to decrease without major variations throughout storage (Figure 2E). The highest average content of soluble solids was observed in fruit harvested ripe; for the other stages, there was no significant difference (Table 2). In Mascot fruit, an increase in the soluble solids was observed in fruit harvested at turning and ripe stages over the storage. In its turn, in fruit harvested at pink and red stages, there was an increase in soluble solids only up to 15 days of storage and subsequent drop in these values (Figure 2F). This reduction in sugar content was also observed in a study carried out by León-Sánchez et al. (2009) in tomato fruit stored under refrigerated environment. 
Figure 2. Longevity of cherry tomato fruit at turning, pink, red and ripe maturity points of the cultivars Perinha Água Branca (PAB) and Mascot stored at controlled temperature $\left(12{ }^{\circ} \mathrm{C}\right.$ and $\left.90 \% \mathrm{RH}\right)$. A and B) Fresh mass loss; $\mathrm{C}$ and $\left.\mathrm{D}\right)$ Titratable acidity; and E and F) Soluble solids. The treatments not presented in the figure were not significant by the $\mathrm{F}$ test at $5 \%$ probability level, within the respective assessed times for PAB and Mascot.
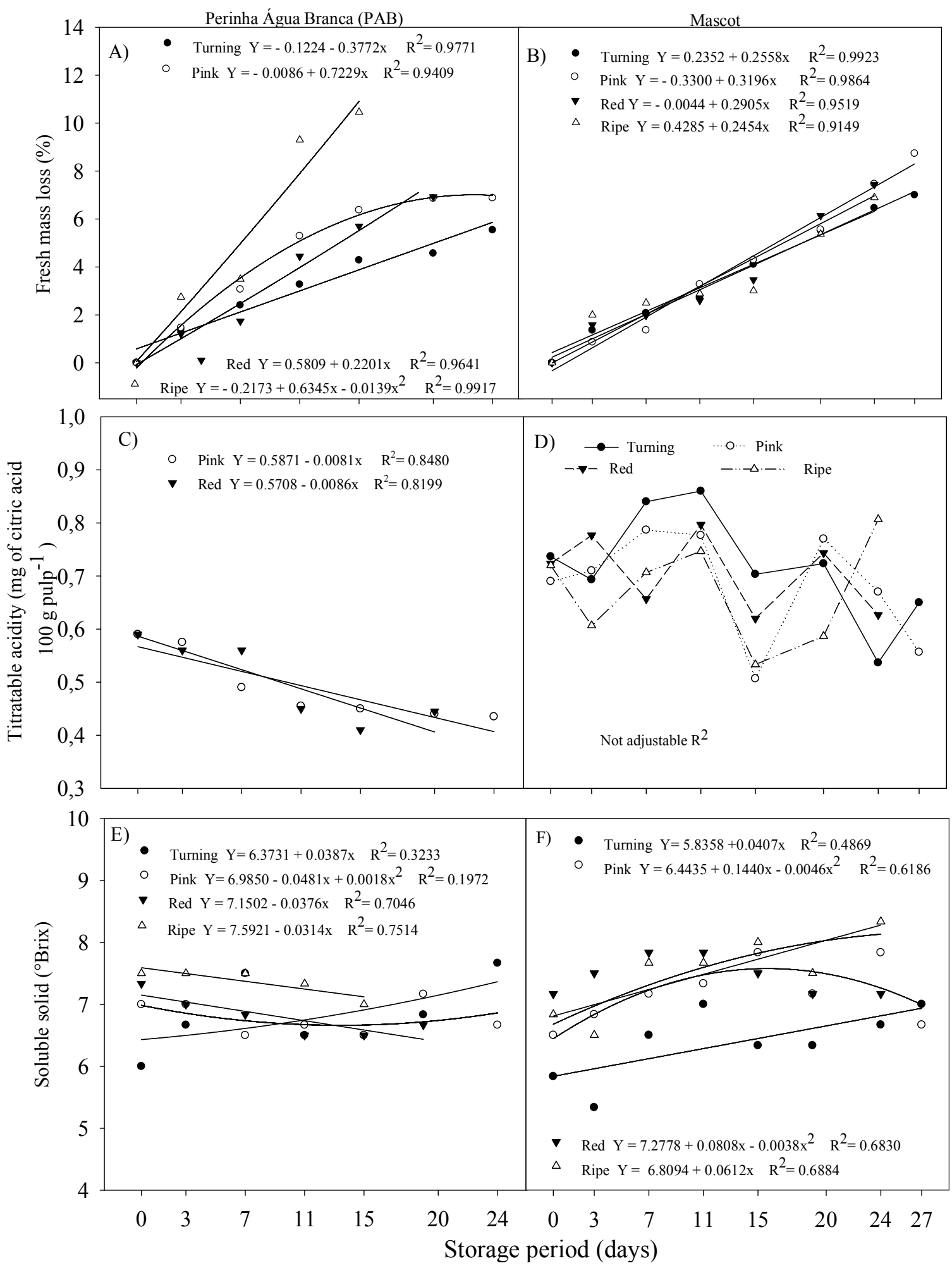
Table 2. Averages of fresh mass loss, $\mathrm{pH}$, titratable acidity, soluble solids and ascorbic acid in fruit of cherry tomato of the cultivars Perinha Água Branca (PAB) and Mascot stored at controlled temperature $\left(12{ }^{\circ} \mathrm{C}\right.$ and $\left.90 \% \mathrm{RH}\right)$.

\begin{tabular}{|c|c|c|c|c|c|c|c|c|c|c|}
\hline \multirow[b]{2}{*}{$\begin{array}{c}\text { Maturity } \\
\text { stages }\end{array}$} & \multicolumn{2}{|c|}{$\begin{array}{l}\text { Fresh mass loss } \\
\qquad(\%)\end{array}$} & \multicolumn{2}{|c|}{$\mathrm{pH}$} & \multicolumn{2}{|c|}{$\begin{array}{l}\text { Titratable acidity } \\
\text { (mg of citric acid } \\
\left.100 \mathrm{~g} \mathrm{pulp}^{-1}\right)\end{array}$} & \multicolumn{2}{|c|}{$\begin{array}{l}\text { Soluble solids } \\
\quad\left({ }^{\circ} \text { Brix }\right)\end{array}$} & \multicolumn{2}{|c|}{$\begin{array}{c}\text { Ascorbic acid } \\
\text { (mg of ascorbic acid } \\
100 \mathrm{~g} \text { of pulp }^{-1} \text { ) }\end{array}$} \\
\hline & PAB & Mascot & PAB & Mascot & PAB & Mascot & PAB & Mascot & PAB & Mascot \\
\hline Turning & $3.06 \mathrm{Ac}$ & 3.66Aa & $4.57 \mathrm{Ac}$ & $4.17 \mathrm{Bb}$ & $0.60 \mathrm{Ba}$ & $0.72 \mathrm{Aa}$ & $6.81 \mathrm{Ab}$ & $6.37 \mathrm{Bb}$ & 34.92Bab & $40.28 \mathrm{Aa}$ \\
\hline Pink & 4.28Aab & $3.94 \mathrm{Aa}$ & $4.84 \mathrm{Ab}$ & $4.22 \mathrm{Bb}$ & $0.49 \mathrm{Bb}$ & $0.68 \mathrm{Aa}$ & $6.78 \mathrm{Bb}$ & 7.17Aa & $44.44 \mathrm{Aa}$ & $34.03 \mathrm{Ba}$ \\
\hline Red & $3.33 \mathrm{Abc}$ & $3.32 \mathrm{Aa}$ & $4.85 \mathrm{Aab}$ & $4.26 \mathrm{Bab}$ & $0.49 \mathrm{Bb}$ & $0.71 \mathrm{Aa}$ & $6.80 \mathrm{Bb}$ & $7.45 \mathrm{Aa}$ & $29.63 \mathrm{Ab}$ & $32.54 \mathrm{Aa}$ \\
\hline Ripe & $5.20 \mathrm{Aa}$ & $3.23 \mathrm{Ba}$ & $4.93 \mathrm{Aa}$ & $4.31 \mathrm{Ba}$ & $0.50 \mathrm{Bb}$ & $0.67 \mathrm{Aa}$ & $7.37 \mathrm{Aa}$ & $7.50 \mathrm{Aa}$ & $43.33 \mathrm{Aa}$ & $33.33 \mathrm{Ba}$ \\
\hline CV (\%) & \multicolumn{2}{|c|}{33.90} & \multicolumn{2}{|c|}{2.49} & \multicolumn{2}{|c|}{12.44} & \multicolumn{2}{|c|}{6.88} & \multicolumn{2}{|c|}{31.72} \\
\hline
\end{tabular}

* Means followed by the same uppercase letters on columns and lowercase letters on rows do not differ significantly by the Tukey's test at $5 \%$ probability.

According to Osm-Oliu et al. (2011), fruit maturation involves changes in its physiology, for example the increase in sugars, such as glucose and fructose, and sucrose reduction. In addition to the degradation of polysaccharides, the fresh mass loss during the maturation process is another factor that results in increased soluble solids due to the accumulation of sugars (CHITARRA; CHITARRA, 2005). Centeno and Neves (2009) found higher levels of soluble solids in ripe fruit compared to green fruit. Such increase was characterized by the increment in fructose and glucose and reduction in the sucrose levels. The fructose contents, associated with the decrease of some organic acids, contribute directly to the flavor of ripe tomatoes.

When comparing the two cultivars, it is observed that at turning stage the soluble solids content of PAB fruit was higher than that observed for Mascot fruit, and no difference between the ripe fruit of both cultivars was observed (Table 2). On the other hand, in fruit harvested at pink and red stages were observed higher soluble solids content in Mascot fruit when compared to PAB. However, these values were always above the value recommended by Morgan (1997), in which soluble solids higher than $5.0^{\circ}$ Brix is an indicative of tomato fruit with high quality. The values for ${ }^{\circ}$ Brix found in both storage conditions confirm the quality of these fruit and their possible acceptance by the consumer market.
The average values of ascorbic acid in PAB fruit ranged from 29.63 to $44.44 \mathrm{mg}$, respectively, at red and pink stages while in Mascot fruit these values ranged from 32.54, for red stage, to $40.28 \mathrm{mg}$, for turning stage, with no significant differences between them (Table 2). The ascorbic acid contents were higher in PAB fruit than in Mascot, except when harvested turning (Table 2). Souza et al. (2011) found average values of 33.83 and $42.66 \mathrm{mg}$ of ascorbic acid respectively to the access 18 and 209 of cherry tomatoes harvested at the commercial maturity point. These values are close to those found in this study for PAB and Mascot.

\section{Conclusions}

The harvest at turning and pink stages, in addition to the storage under controlled conditions, preserves for a longer time the physical and chemical quality indexes, contributing to higher shelf life of fruit.

The longevity estimated for each cultivar allows the farmer a better planning of the optimal harvest point and the best storage system considering the distance of the consumer market. 


\section{Acknowledgements}

To the Graduate Program in Plant Science of the Federal Rural University of Rio de Janeiro. To the CAPES and CNPq for the financial support.

\section{References}

AGUIAR, F. P. C.; ABRAHÃO, R. M. S.; ANJOS, V. D. A.; BENATO, E. A. Determinação da vida útil de tomate tipo cereja e 'Sweet Grape'. In: CONGRESSO INTERINSTITUCIONAL DE INICIAÇÃO CIENTÍFICA, 6., 2012, Jaguariúna. Anais... Jaguariúna: Embrapa Meio Ambiente, 2012. p. 1-10.

ALEXANDER, L.; GRIERSON, D. Ethylene biosynthesis and action in tomato: a model for climacteric fruit ripening. Journal of Experimental Botany, UK, v. 53, n. 377, p. 2039-2055, 2002.

ANTHON, G. E.; LE STRANGE, M.; BARRETT, D. M. Changes in $\mathrm{pH}$, acids, sugars and other quality parameters during extended vine holding of ripe processing tomatoes. Jornal of the Science of Food and Agriculture, London, v. 91, n. 7, p. 1175-1181, 2011.

BRACKMANN, A.; STEFFENS, C. A.; ANDRIOLO, J. L.; PINTO, J. A. V. Armazenamento de tomate cultivar "Cronus" em função do estádio de maturação e da temperatura. Ciência Rural, Santa Maria, v. 37, n. 5, p. 1295-1300, 2007.

BRASIL. Ministério da Agricultura do Abastecimento e da Reforma Agrária. Portaria ${ }^{\circ} 553$ de 30 de agosto de 1995. Dispõe sobre a norma de identidade, qualidade, acondicionamento e embalagem do tomate in natura, para fins de comercialização e revoga as especificações de identidade, qualidade, acondicionamento e embalagem do tomate, estabelecidas pela Portaria $\mathrm{n}^{\circ} 76$, de 25 de fevereiro de 1975. Diário Oficial [da] República Federativa do Brasil, Brasília, set. 1995. Seção 1, p. 1-8.

Ministério da Agricultura. Portaria $\mathrm{n}^{\circ} 76$ de 26 de novembro de 1986. Dispõe sobre os métodos analíticos de bebidas e vinagre. Diário Oficial [da] República Federativa do Brasil, Brasília, nov. 1986. Seção 1, p. 1.

BRON, I. U.; JACOMINO, A. P. Ripening and quality of 'Golden' papaya fruit harvested at different maturity stages. Brazilian Journal of Plant Physiology, Londrina, v. 18, n. 3, p. 389-396, 2006.

CASA, J.; EVANGELISTA, R. M. Influência das épocas de colheita na qualidade de tomate cultivado em sistemas alternativos. Semina: Ciências Agrárias, Londrina, v. 30, n. 1, p. 1101-1108, 2009.
CENTENO, D. C.; NEVES, N. R. Contribuidores do sabor em tomates (Solanum lycopersicum var. Moneymaker) e suas inter-relações. Revista Trópica: Ciência Agrárias e Biológicas, Chapadinha, v. 3, n. 2, p. 4-11, 2009.

CHITARRA, M. L. F.; CHITARRA, A. B. Pós-colheita de frutos e hortaliças: fisiologia e manuseio. 2. ed. Lavras: UFLA, 2005. 785p.

COSTA, A. L.; RIBEIRO, L. R.; KOBLITZ, M. G. B. Uso de atmosfera controlada e modificada em frutos climatéricos e não-climatéricos. Sitientibus série Ciências Biológicas, Feira de Santana, v. 11, n. 1, p. 1-7, 2011.

FERREIRA, D. F. Análises estatísticas por meio do Sisvar para Windows versão 4.0. In: REUNIÃO ANUAL DA REGIÃO BRASILEIRA DA SOCIEDADE INTERNACIONAL DE BIOMETRIA, n. 45, 2000, São Carlos. Anais... São Carlos: UFSCar, 2000. p. 255-258.

FERREIRA, R. M. A.; LOPES, W. A. R.; AROUCHA, E. M. M.; MANO, N. C. S.; SOUSA, C. M. G. Caracterização física e química de híbridos de tomate em diferentes estádios de maturação produzidos em Baraúna, Rio Grande do Norte. Revista Ceres, Viçosa, v. 59, n. 4, p. 506-511, 2012.

FERREIRA, S. M. R.; QUADROS, D. A.; KARKLE, E. N. L.; LIMA, J. J.; TULLIO, L. T.; FREITAS, R. J. S. Qualidade pós-colheita do tomate de mesa convencional e orgânico. Ciência Tecnologia Alimentos, Campinas, v. 30, n. 4, p. 858-864, 2010.

GUILHERME, D. O.; PINHO, L.; CAVALCANTI, T. F. M.; COSTA, C. A.; ALMEIDA, A. C. Análise sensorial e físico-química de frutos tomate cereja orgânicos. Revista Caatinga, Mossoró, v. 27, n. 1, p. 181-186, 2014.

INSTITUTO ADOLFO LUTZ - IAL. Normas analíticas do Instituto Adolfo Lutz. Métodos físico-químicos para análise de alimentos. 4. ed. São Paulo: IAL, 2008. 1020 p.

INSTITUTO DE TECNOLOGIA DE ALIMENTOS ITAL. Manual técnico de análise química de alimentos. Campinas: ITAL, 1990. $121 \mathrm{p}$.

JAVANMARDI, J.; KUBOTA, C. Variation of lycopene, antioxidant activity, total soluble solids and weight loss of tomato during postharvest storage. Postharvest Biology and Technology, Amsterdam, v. 41, n. 2, p. 151155, 2006.

KLUGE, R. A.; RODRIGUES, D. S.; KALIL, G. P. C.; RUSSO, R.; LUCAS, M. B.; MINAMI, K. Influência do estádio de maturação e da cobertura com polietileno na conservação de tomates frigorificados. Scientia Agrícola [online], Piracicaba, v. 53, n. 1, p. 6-13, 1996. 
LEMOS, O. L.; REBOUÇAS, T. N. H.; JOSÉ, A. R. S.; VILA, M. T. R.; SILVA, K. S.; SILVA, D. S.; BARRETO, A. P. P.; BOMFIM, M. P. Conservação do pimentão "magali" em duas condições de armazenamento associada à atmosfera modificada. Magistra, Cruz das Almas, v. 20, n. 1, p. 06-15, 2008.

LEÓN-SÁNCHEZ, F. D.; PELAYO-ZALDÍVAR, C.; RIVERA-CABRERA, F.; PONCE-VALADEZ, M.; ÁVILA-ALEJANDRE, X.; FERNÁDEZ, F. J.; ESCALONA-BUENDÍA, H. B.; PÉREZ-FLORES, L. J. Effect of refrigerated storage on aroma and alcohol dehydrogenase activity in tomato fruit. Postharvest Biology and Technology, Amsterdam, v. 54, n. 2, p. 93100, 2009.

LUENGO, R. F. A. Armazenamento refrigerado. In: LUENGO, R. F. A.; CALBO, A. G. Armazenamento de hortaliças. Brasília: Embrapa Hortaliças, 2001, p. 60-65.

MIZOBUTSI, G. P.; SILVA, J. M.; MIZOBUTSI, E. H.; RODRIGUES, M. L. M.; LOPES, R. S.; FERNANDES, M. B.; OLIVEIRA, F. S. Conservação de pinha com uso de atmosfera modificada e refrigeração. Revista Ceres, Viçosa, v. 59, n. 6, p. 751-757, 2012.

MONTEIRO, C. S.; BALBI, M. E.; MIGUEL, O. G.; PENTEADO, P. T. P. S.; HARACEMIV, S. M. C. Qualidade nutricional e antioxidante do tomate "tipo italiano". Alimentos Nutrição, Araraquara, v. 19, n. 1, p. 25-31, 2008.

MORGAN, L. Hydroponic fruit quality and testing. Pratical Hydroponics \& Greenhouses, v. 1, n. 34, p. 2131, 1997.
OLIVEIRA, C. M.; CONEGLIAN, R. C. C.; CARMO, M. G. F. Conservação pós-colheita de tomate cereja revestidos com película de fécula de mandioca. Horticultura Brasileira, Vitória da Conquista, v. 33, n. 4, p. 471-479, 2015.

OPARA, U. L.; AL-ANI, M. R.; AL-RAHBI, N. M. Effect of fruit ripening stage on physico-chemical properties, nutritional composition and antioxidant components of tomato (Lycopersicum esculentum) cultivars. Food and Bioprocess Technology, New York, v. 5, n. 8, p. 32363243, 2012.

OSM-OLIU, G.; HERTOG, M. L. A. T. M.; VAN DE POEL, B.; AMPOFO-ASIAMA, J.; GEERAERD, A. H.; NICOLAI, B. M. Metabolic characterization of tomato fruit during preharvest development, ripening, and postharvest shelf-life. Postharvest Biology and Technology, Amsterdam, v. 62, n. 1, p. 7-16, 2011.

PEARSON, D. The chemical analysis of foods. New York: Chemical Public, 1976. 393 p.

SOUZA A. A.; GRIGIO, M. L.; NASCIMENTO, C. R.; SILVA, A. C. D.; REGO, E. R.; REGO, M. M. Caracterização química e física de frutos de diferentes acessos de tomateiro em casa de vegetação. Revista Agro@mbiente On-line, Boa Vista, v. 5, n. 2, p. 113-118, 2011.

XIN, Y.; CHEN, F.; YANG, H. Morphology, profile and role of chelate-soluble pectin on tomato properties during ripening. Food Chemistry, England, v. 121, n. 2, p. 372$380,2010$. 
